Tersedia online di: http://ejournal-balitbang.kkp.go.id/index.php/bawal
e-mail:bawal.puslitbangkan@ gmail.com
BAWAL WIDYA RISET PERIKANAN TANGKAP
Volume 11 Nomor 3 Desember 2019
p-ISSN: 1907-8226
e-ISSN: 2502-6410
BAWAL
Nomor Akreditasi Kementerian RISTEKDIKTI: 21/E/KPT/2018

\title{
PERIKANAN TUNA SIRIP KUNING (Thunnus albacares Bonnaterre, 1788) PADA ARMADA TONDA DI SAMUDERA HINDIA SELATAN JAWA
}

\section{YELLOWFIN TUNA (Thunnus albacares Bonnaterre, 1788) FISHERIES ON TROLL LINE FLEET IN THE INDIAN OCEAN PART OF SOUTH JAVA}

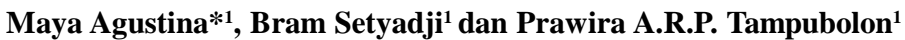

${ }^{1}$ Loka Riset Perikanan Tuna, Denpasar, Jl. Mertasari No. 140, Br. Suwung Kangin, Sidakarya, Denpasar, Bali 80224, Indonesia Teregistrasi I tanggal: 31 Mei 2019; Diterima setelah perbaikan tanggal: 18 Februari 2020;

Disetujui terbit tanggal: 18 Februari 2020

\begin{abstract}
ABSTRAK
Tuna sirip kuning (Thunnus albacares) merupakan hasil tangkapan terbanyak dibandingkan dengan jenis tuna lainnya di Indonesia. Ketersediaan stok tuna sirip kuning di Samudra Hindia, pada saat ini, diperkirakan dalam keadaan lebih tangkap. Oleh karena itu, pengelolaan secara tepat dan bertanggungjawab penting dilakukan untuk melindungi spesies tuna, salah satu caranya dengan mengkaji alat tangkap yang digunakan. Tulisan ini bertujuan untuk mengungkapkan produktivitas dan hasil tangkapan armada tonda, serta struktur ukuran dan hubungan panjang bobot ikan tuna sirip kuning yang di daratkan di selatan Jawa. Komposisi tangkapan tertinggi dari armada tonda diseluruh pendaratan ikan tuna di selatan Jawa terdiri atas tuna sirip kuning dan cakalang. Analisis CPUE menunjukkan hasil yang fluktuatif di setiap lokasi pendaratan tuna sirip kuning di Selatan Jawa. Tuna sirip kuning yang tertangkap di selatan Jawa dengan armada tonda sebagian besar adalah ikan yang belum layak tangkap karena berukuran kurang dari $100 \mathrm{cmFL}$. Struktur ukuran panjang tuna sirip kuning yang tertangkap semakin ke Timur semakin panjang ukurannya. Pola pertumbuhan tuna sirip kuning yang tertangkap di Binuangeun memiliki pola isometrik, PPN Palabuhanratu bersifat allometrik Positif, PPP Sadeng, P2SKP Pacitan, PPN Prigi dan P2SKP Sendang Biru bersifat allometrik negatif.
\end{abstract}

Kata Kunci: Armada tonda; CPUE; pola pertumbuhan; tuna sirip kuning

\begin{abstract}
Yellowfin tuna (Thunnus albacares) is the largest catch compared to other tuna species in Indonesia. The availability of yellowfin tuna stock in the Indian Ocean, at present, is estimated to be in overfished condition. Therefore, proper and responsible management is important to protect the species. One of the ways is by studying the used fishing gear. This paper aims at determining vessel's productivity, as well as composition, size structure and length-weight relationship of yellowfin tun a catches from troll line fleet in the Indian Ocean part of south Java. The highest catch of tuna in all of the troll line landing places was yellowfin tuna, following by skipjack tuna. CPUE analysis showed fluctuating results at each landing site. Yellowfin tuna sizes caught by troll line fleet were mostly less than $100 \mathrm{cmFL}$ and categorized as should not be properly caught. Geographically, getting to the east the average size of the catches tend to be larger. The growth pattern of yellowfin tuna catches landed in Binuangeun was isometric; Palabuhanratu was positive allometric; while those landed in Sadeng, Pacitan, Prigi and Sendang Biru were negative allometric.
\end{abstract}

Keywords: Troll line; CPUE; growth pattern; yellowfin tuna 


\section{PENDAHULUAN}

Sumberdaya ikan pelagis besar di Wilayah Pengelolaan Perikanan (WPP) 573 merupakan salah satu komoditas penting perikanan Indonesia yang sudah dieksploitasi sejak lama. Tuna sirip kuning (Thunnus albacares) merupakan hasil tangkapan terbanyak dibandingkan dengan jenis tuna lainnya di Indonesia. Hasil tangkapan tuna di Indonesia secara keseluruhan pada kurun waktu 2004 hingga 2011 mencapai 1.297.062 ton, dari jumlah ini sebanyak $69 \%$ hasil tangkapan adalah tuna sirip kuning (Direktorat Jenderal Perikanan Tangkap, 2012). Tingginya permintaan tuna sirip kuning di pasar dunia dalam beberapa tahun terakhir berdampak terhadap pemanfaatan yang makin intensif. Hal ini membuat ketersediaan stok tuna sirip kuning (yellowfin tuna) di Samudra Hindia diperkirakan pada saat ini, dalam keadaan lebih tangkap (IOTC, 2016). Kondisi ini akan menjadi lebih buruk lagi jika sumber daya ini tidak dikelola dengan lebih baik. Oleh karena itu, pengelolaan secara tepat dan bertanggungjawab penting dilakukan untuk melindungi spesies tuna. Salah satunya dengan mengkaji alat tangkap yang digunakan.

Pemanfaatan sumber daya tuna pada perikanan skala kecil di berbagai daerah di Indonesia banyak menggunakan armada tonda. Salah satu alat tangkap yang digunakan oleh armada tonda yaitu pancing ulur. Menurut Nurdin et al., (2015) alat tangkap pancing ulur banyak dioperasikan oleh nelayan skala kecil (artisanal) di Palabuhanratu dan jumlah armada tonda terus meningkat setiap tahunnya. Alat tangkap pancing ulur juga digunakan oleh nelayan Sendang Biru untuk menangkap tuna di perairan Samudera Hindia (Nurdin \& Nugroho, 2007). Tuna sirip kuning merupakan salah satu hasil tangkapan utama dari nelayan pancing ulur yang beroperasi di perairan sekitar rumpon Muhammad \& Barata, (2012). Pancing ulur sendiri pertama kali dikenalkan oleh nelayan bugis yang berada di Sendang Biru, Malang. Mulai tahun 2005 hingga tahun 2009 pancing ulur jumlahnya lebih banyak dari jaring insang (Anggawangsa \& Hargiyatno, 2012 dalam Hargiyatno et al., 2013). Pancing ulur sering juga disebut sebagai pancing tonda. Jumlah nelayan yang menggunakan pancing ulur terus meningkat setiap tahunnya. Peningkatan ini terjadi karena pengoperasian pancing ulur (pancing tonda) memiliki banyak keunggulan yaitu biaya operasi yang relatif kecil, hasil tangkapan yang merupakan komoditas ekspor, operasi penangkapan tidak tergantung pada musim ikan, daerah penangkapan sudah pasti pada rumpon yang dipasang dan produktivitas penangkapan yang tinggi (Wudianto et al., 2003). Keunggulankeunggulan pengoperasian pancing ulur dikarenakan dalam satu armada penangkapan dioperasikan empat alat tangkap sekaligus (Hargiyatno et al., 2013).

Untuk menjamin kelangsungan usaha pemanfaatan dan kelestarian sumber daya ikan perlu diupayakan manajemen yang tepat. Tulisan ini menyajikan Informasi mengenai produktivitas armada tonda, hasil tangkapan, struktur ukuran dan panjang berat ikan di WPP 573 sehingga dapat menjadi bahan pendukung dalam menentukan langkah-langkah pengelolaan untuk mewujudkan pemanfaatan sumber daya tuna sirip kuning yang bertanggung jawab dan berkelanjutan.

\section{BAHANDANMETODE Pengumpulan Data}

Pengambilan data dilakukan di beberapa pelabuhan yang berada di selatan Jawa dengan tenggang waktu Maret - Desember 2016. Lokasi pengambilan sampel yaitu PPI Binuangeun, PPN Palabuhanratu, PPP Sadeng, P2SKP Tamperan Pacitan, PPN Prigi dan P2SKP Pondokdadap Sendang Biru (Gambar 1). Data primer diperoleh melalui enumerasi. Dari data enumerasi yang terkumpul, diperoleh data total pengukuran panjang sebanyak 16.925 ekor tuna sirip kuning yang didaratkan di Pelabuhan Perikanan di selatan Jawa. Hasil pengukuran panjang tuna sirip kuning di PPI Binuangeun sebanyak 3.747 ekor, PPN Palabuhanratu ikan yang diukur sebanyak 1.166 ekor, PPI Sadeng sebanyak 960 ekor, P2SKP Tamperan sebanyak 4089 ekor, PPN Prigi ikan yang dapat diukur sebanyak 4161 ekor dan P2SKP Pondokdadap Sendang Biru sebanyak 2.602 ekor.

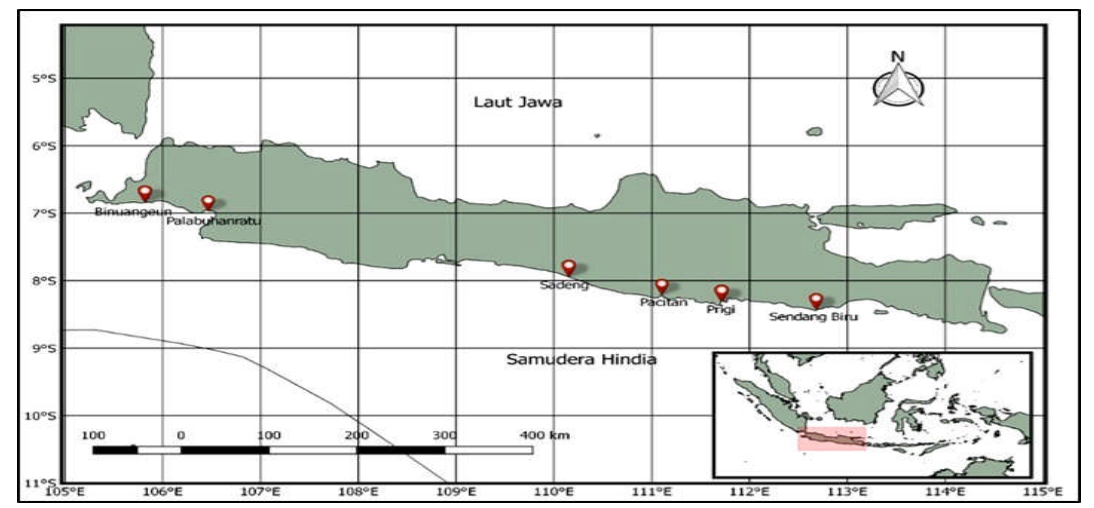

Gambar 1. Lokasi pengambilan sampel ikan.

Figure 1. Location of fish sampling. 
Beberapa daerah di selatan Jawa memiliki alat tangkap pancing ulur yang sama jenisnya biasanya hanya sebutannya saja yang berbeda. Setiap alat tangkap yang dioperasikan memiliki karakteristik umpan dan waktu penangkapan yang bervariasi. Jenis - jenis umum alat tangkap pancing ulur yang digunakan nelayan dalam menangkap ikan tuna (Thunnus sp) adalah pancing tonda (pancing tonda panjang), pancing taber, pancing tomba, pancing coping dan pancing layang-layang. Alat-alat tangkap tersebut dioperasikan dalam satu armada penangkap ikan yang disebut armada tonda. Adapun spesifikasi maupun cara pengoperasian alat-alat tangkap armada tonda adalah sebagai berikut:

\section{Pancing tonda (pancing tonda panjang)}

Pancing tonda terdiri atas tali utama, kili-kili, tali cabang dan pancing. Tali utama berbahan monofilamen No. $80-$ 100 memiliki panjang $120 \mathrm{~m}$, kili-kili berjumlah $1-2$ buah, sedangkan tali cabang memiliki panjang 7,5 m dengan bahan monofilamen No. 50 -70. Dalam setiap setting pancing yang digunakan adalah sebanyak 5 pancing dengan no. 7 dan diberi umpan buatan dari tali serabut sutra. Pancing tonda dioperasikan dengan target tangkapan adalah ikan-ikan yang berenang di permukaan air laut seperti tuna dan cakalang. Pancing Tonda banyak digunakan oleh nelayan Binuangeun, Palabuhanratu, Sadeng, Prigi, Pacitan dan Sendang Biru. Nelayan Sendang Biru menggunakan batu sebagai pemberat.

\section{Pancing taber}

Pancing taber terdiri atas tali utama memiliki panjang $30 \mathrm{~m}$ berbahan monofilamen No. 200, tali cabang utama memiliki panjang 13,5 - 22,5 m berbahan monofilamen No. 140, sedangkan tali cabang pancing memiliki panjang $1 \mathrm{~m}$ berbahan monofilamen No. 100 dengan diameter 0,8 mm. Pancing yang digunakan No. 6 dengan jumlah 50 buah dan pemberat timah dengan berat 5 ons serta menggunakan umpan tiruan berupa rumbaian benang sutra atau tali plastik rafia atau kain perca yang berwarna-warni sehingga menarik perhatian ikan. Target penangkapan pancing ini adalah yuwana tuna dan cakalang. Pancing ini banyak digunakan di Palabuhanratu dan Prigi

\section{Pancing tomba/ Pancing pelampung}

Pancing tomba dioperasikan dengan melepaskan pancing yang terikat pada pelampung ke dalam air laut. Konstruksi pancing ini cukup sederhana hanya mengikat tali pancing pada pelampung yang menggunakan jerigen. Umpan yang digunakan adalah umpan hidup berukuran kecil seperti tongkol dan cakalang. Tali utama yang digunakan berbahan monofilamen No. 300 dengan panjang $75 \mathrm{~m}$. Pancing ini dilengkapi pemberat dari timah baja 100 gr yang dipasang sekitar $15 \mathrm{~m}$ di atas tali cabang. Tali cabang berbahan monofilamen No. 200 dengan panjang $15 \mathrm{~m}$, serta dilengkapi kili-kili. Pancing yang digunakan yaitu No. 3. Dalam setiap setting menggunakan 5-12 pancing. Target penangkapan pancing tomba adalah tuna berukuran besar dan juga jenis ikan marlin (Fam. Istiophoridae). Pancing ini banyak digunakan di Palabuhanratu

\section{Pancing coping}

Pancing coping terdiri atas tali utama, tali cabang, pemberat dan pancing. Tali utama memiliki panjang sekitar 80 - 100 m berbahan monofilamen No. 150. Tali cabang memiliki panjang 7,5 m berbahan monofilamen No. 50 . Pemberat terbuat dari timah dengan berat $1 \mathrm{~kg}$ dan pancing yang digunakan tipe J No. 7 dengan menggunakan umpan buatan dari kepingan DVD dan bekas botol oli. Pengoperasian pancing coping setelah selesai menggunakan pancing taber. Pengoperasian pancing coping dilakukan saat kapal berjalan pelan memotong arus di arah depan rumpon. Pancing diturunkan pada kedalaman tertentu, kemudian pemberat timah dipegang dan dilemparkan sehingga pancing yang sudah dipasang umpan bergerak di dalam air laut untuk menarik perhatian ikan. Pancing ditarik secara perlahan sambil menggerakkan umpan sampai ke permukaan dan terlihat kondisi pancing dalam keadaan baik untuk diturunkan kembali ke perairan. Target penangkapan pancing coping adalah cakalang dan yuwana tuna. Pancing ini banyak digunakan di Palabuhanratu dan Prigi

\section{Pancing layang - layang}

Pancing layang-layang dioperasikan dengan menggunakan bantuan angin. Apabila angin kencang maka digunakan layang-layang berukuran kecil, sedangkan apabila angin tidak kencang digunakan layang-layang berukuran besar. Layang-layang diterbangkan dan digerakkan sehingga umpan terlihat berada di permukaan air laut dan bergerak-gerak menyerupai umpan hidup. Umpan yang digunakan adalah umpan buatan yang menyerupai cumi dan ikan lemuru yang terbuat dari bahan karet silikon. Tali yang digunakan terbuat dari monofilamen No. 300 dengan panjang 13,5 m. Dilengkapi kili-kili setelah ikatan pada layang-layang. Pancing yang digunakan adalah pancing cabang 3 tipe J No. 3 digabung dan terangkai pada umpan buatan. Pancing ini banyak digunakan nelayan Binuangeun, Palabuhanratu, Sadeng, Prigi, Pacitan dan Sendang Biru.

\section{Analisis Data}

Data biologi ikan yang dikumpulkan berupa data panjang dan bobot ikan yang diperoleh dari pencatatan enumerator daerah LRPT terhadap pendaratan hasil tangkapan armada tonda. Kemudian data tersebut di analisis berdasarkan:

\section{Komposisi Hasil Tangkapan}

Data yang dikumpulkan adalah jenis ikan yang tertangkap, jumlah hasil tangkapan untuk setiap jenis ikan, 
dan ukuran panjang ikan yang tertangkap. Setelah data tersebut diperoleh, dilakukan tabulasi data untuk memisahkan komposisi hasil tangkapan berdasarkan jenis ikan dan armada penangkapannya. Komposisi hasil tangkapan dinyatakan dalam persen dan dianalisis dengan pendekatan deskriptif, yang disajikan dalam bentuk grafik.

\section{Catch Per-Unit of Effort (CPUE)}

Catch per-unit of Effort (CPUE) dihitung dengan menggunakan rumus Sparre \& Venema (1999):

$$
\text { CPUE }=\frac{\text { Catch }}{\text { Effort }}
$$

Dimana:

$$
\begin{aligned}
& \text { CPUE : Catch per unit of effort } \\
& \text { Catch : Jumlah hasil tangkapan }(\mathrm{kg}) \\
& \text { Effort : Jumlah upaya (hari) }
\end{aligned}
$$

\section{Sebaran Panjang}

Sebaran frekuensi panjang disajikan dalam bentuk grafik untuk melihat sebaran ukurannya. Dari grafik tersebut dapat terlihat puncak (modus) yang menggambarkan ukuran ikan paling banyak tertangkap dengan alat tangkap pancing ulur kemudian dibandingkan dengan ukuran pertama kali ikan memijah (Lm) dengan studi pustaka.

\section{Hubungan Panjang Berat}

Analisis hubungan panjang-berat ikan menggunakan rumus Effendie (2002):

$$
W=a L^{b}
$$

\section{Dimana:}

$W=$ berat ikan $(\mathrm{kg})$

$L=$ panjang cagak ikan $(\mathrm{cm})$

$a=$ intercept (perpotongan antara garis regresi dengan sumbu y)

$b=$ koefisien regresi (sudut kemiringan garis)

Pola pertumbuhan ikan yang diamati dapat diketahui dari persamaan tersebut. Nilai b yang diperoleh digunakan untuk menentukan pola pertumbuhan dengan kriteria:

a. Jika $b=3$, pertumbuhan bersifat isometrik, yaitu pertambahan panjang sama dengan pertambahan berat,

b. Jika $b>3$, maka pola pertumbuhan bersifat allometrik positif, yaitu pertambahan berat lebih cepat daripada pertambahan panjangnya, c. Jika $b<3$, maka pola pertumbuhan bersifat allometrik negatif, yaitu pertambahan panjang lebih cepat daripada pertambahan berat.

Untuk mengetahui apakah nilai b yang diperoleh lebih besar, sama dengan atau lebih kecil dari 3 digunakan uji t pada selang kepercayaan 95\% (Steel \& Torrie, 1989).

\section{Faktor Kondisi}

Analisis faktor kondisi dilakukan pada setiap kisaran panjang dan setiap bulan. Faktor kondisi dihitung dengan membandingkan berat rata-rata ikan dengan berat prediksi yang diperoleh dari parameter penghitungan panjang berat secara umum. Metode yang digunakan untuk penghitungan faktor kondisi relatif menggunakan rumus King (2007):

$$
K_{n}=\frac{W_{m}}{W_{p}}
$$

Dimana:

$$
\begin{aligned}
K_{n}= & \text { factor kondisi relatif } \\
W_{m}= & \text { rata-rata berat } \\
W_{p}= & \text { berat prediksi dari berat ikan pada ukuran yang } \\
& \text { sama }
\end{aligned}
$$

\section{HASIL DAN BAHASAN Hasil}

\section{Komposisi Hasil Tangkapan}

Komposisi hasil tangkapan armada tonda tahun 2016 yang didaratkan di pelabuhan selatan Jawa memiliki kesamaan disetiap lokasinya. Secar umum, hasil tangkapan tertinggi adalah tuna sirip kuning (YFT) dan cakalang (SKJ), diikuti oleh albakor, lemadang, tuna mata besar serta hasil samping lainnya. Hasil tangkapan di PPI Binuangeun didominasi oleh tuna sirip kuning sebanyak $34 \%$ dan cakalang sebanyak $32 \%$ sedangkan di PPN Palabuhanratu didominasi oleh tuna sirip kuning sebanyak $47.96 \%$ kemudian diikuti cakalang 33.23\%. Komposisi hasil tangkapan di PPP Sadeng didominasi oleh yuwana tuna dan cakalang masing-masing sebanyak $51 \%$ dan $31 \%$. Komposisi hasil tangkapan yang didaratkan di P2SKP Tamperan Pacitan tahun 2016 didominasi oleh yuwana tuna dan albakor sebanyak $37 \%$ dan $18 \%$, sedangkan di PPN Prigi didominasi oleh juwana tuna dan tuna sirip kuning sebanyak $28 \%$ dan $22 \%$. Sementara itu, di P2SKP Pondokdadap Sendang Biru sedikit berbeda, hasil tangkapan didominasi oleh ikan albakora dan tuna sirip kuning sebanyak $43 \%$ dan $41 \%$ (Gambar 2). 


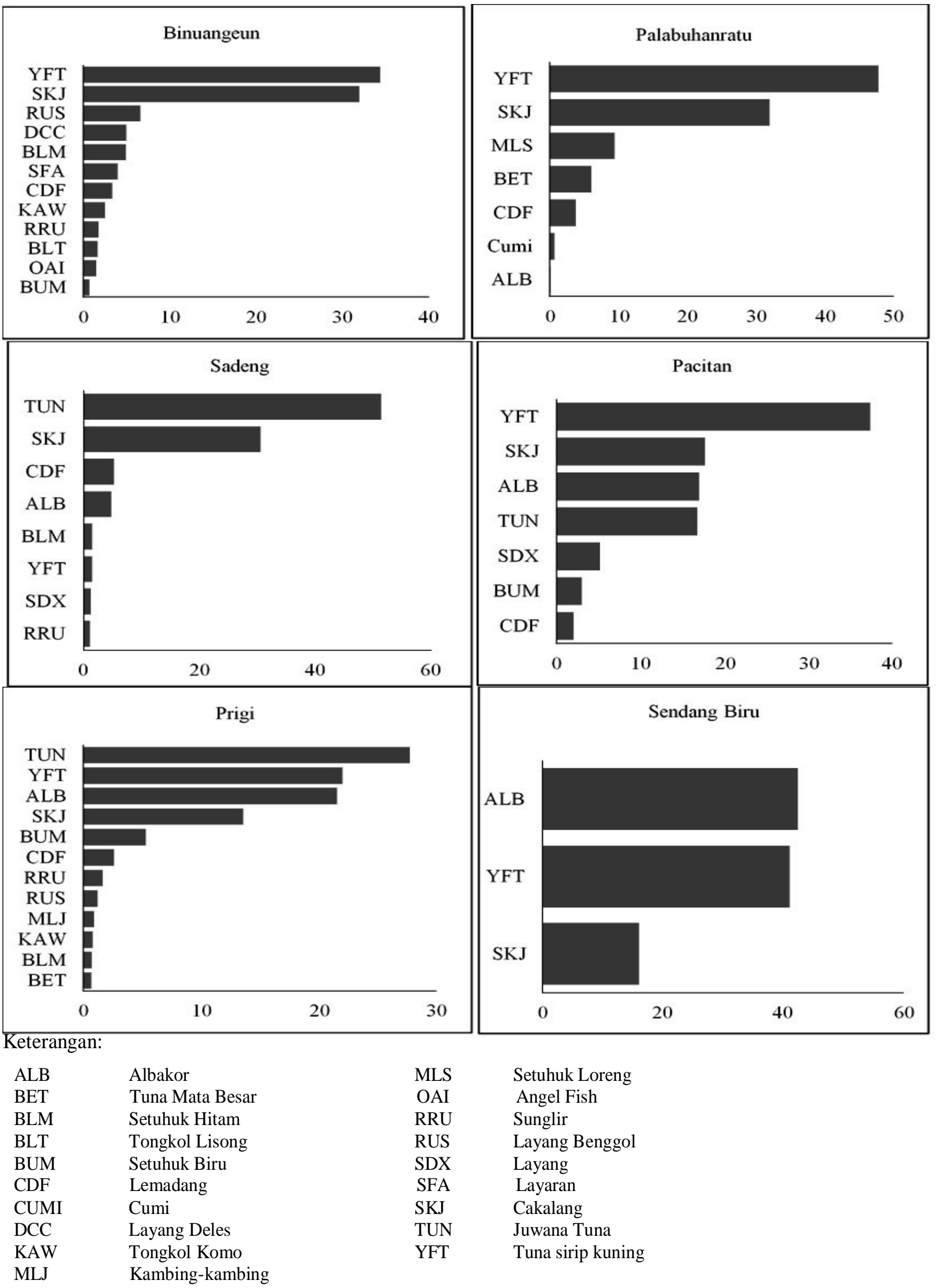

Gambar 2. Komposisi hasil tangkapan armada tonda.

Figure 2. Troll line catch composition. 
Catch Per-Unit of Effort (CPUE) Tuna Sirip Kuning

Berdasarkan analisis CPUE tuna sirip kuning menunjukkan hasil yang fluktuatif disetiap lokasi pendaratan tuna sirip kuning di selatan Jawa. Untuk Lokasi Binuangeun, CPUE tertinggi diperoleh pada bulan April dan terendah pada bulan Agustus, untuk lokasi Sadeng tertinggi terjadi pada September dan terendah bulan Juli,
November dan Desember. Sedangkan di Pacitan CPUE tertinggi diperoleh pada bulan Juli dan terendah pada bulan April. CPUE tertinggi di Prigi terdapat pada bulan April dan terendah pada bulan September, sementara di Sendang Biru tertinggi terjadi pada bulan April dan terendah bulan Juli (Gambar 3). CPUE Palabuhanratu tidak dapat ditampilkan karena data yang diperoleh tidak dilengkapi dengan jumlah hari laut.

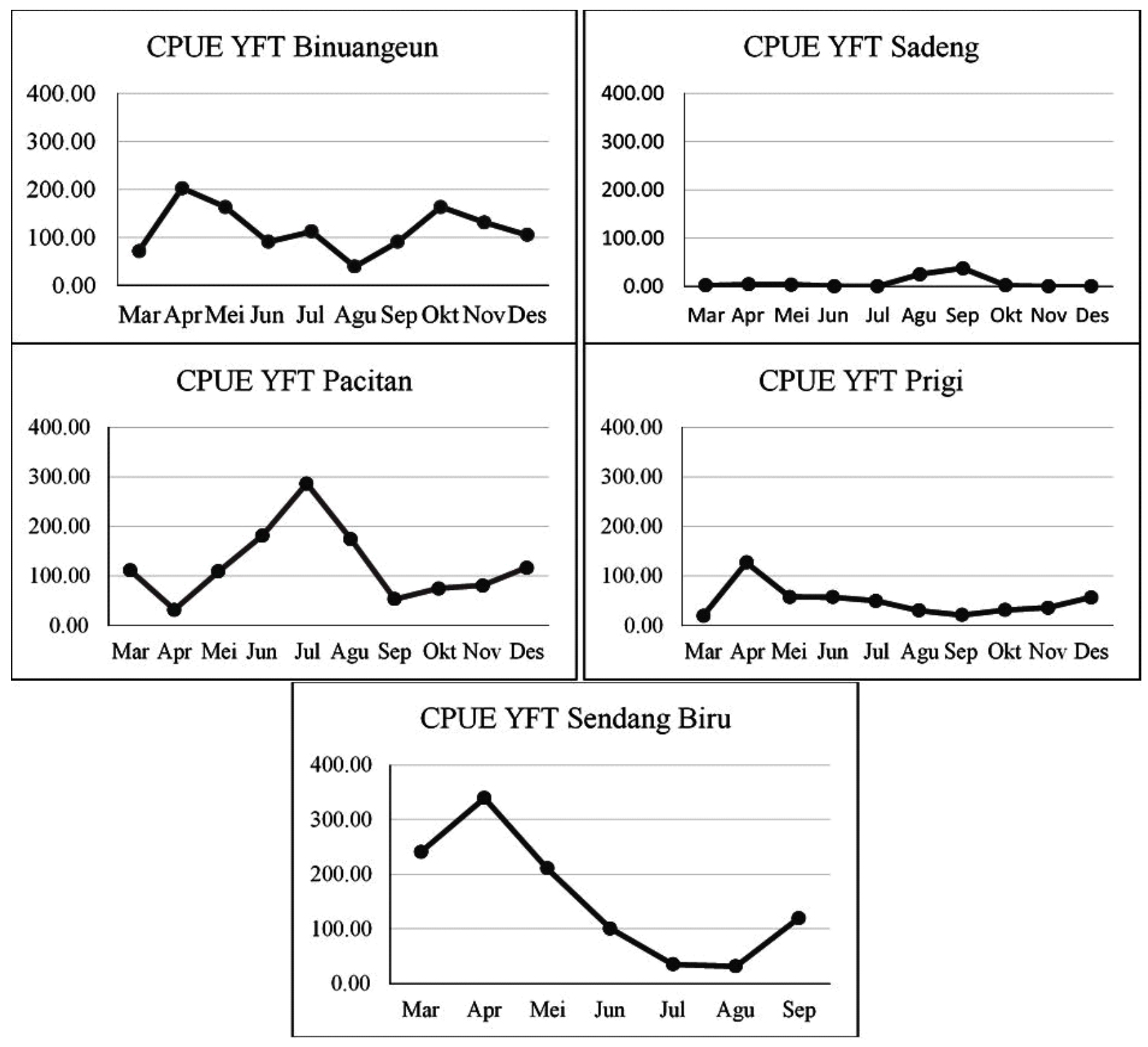

Gambar 3. CPUE bulanan tuna sirip kuning per lokasi.

Figure 3. Monthly CPUE of yellowfin tuna by sampling location.

\section{Sebaran Panjang}

Hasil pengukuran panjang tuna sirip kuning di PPI Binuangeun berkisar antara 23-168 cm FL yang didominasi oleh ukuran $26-50 \mathrm{~cm}$ FL. Sedangkan di PPN Palabuhanratu ukuran panjang yang diperoleh antara 15
- $156 \mathrm{~cm}$ FL, PPI Sadeng didominasi ukuran panjang antara $23-53 \mathrm{cmFL}$, P2SKP Tamperan didominasi ukuran antara $32-56 \mathrm{~cm}$ FL, PPN Prigi ikan didominasi ukuran 32 - $50 \mathrm{~cm}$ FL dan P2SKP Pondokdadap Sendang Biru didominasi ukuran panjang $32-65 \mathrm{~cm} \mathrm{FL}$ (Gambar 4). 


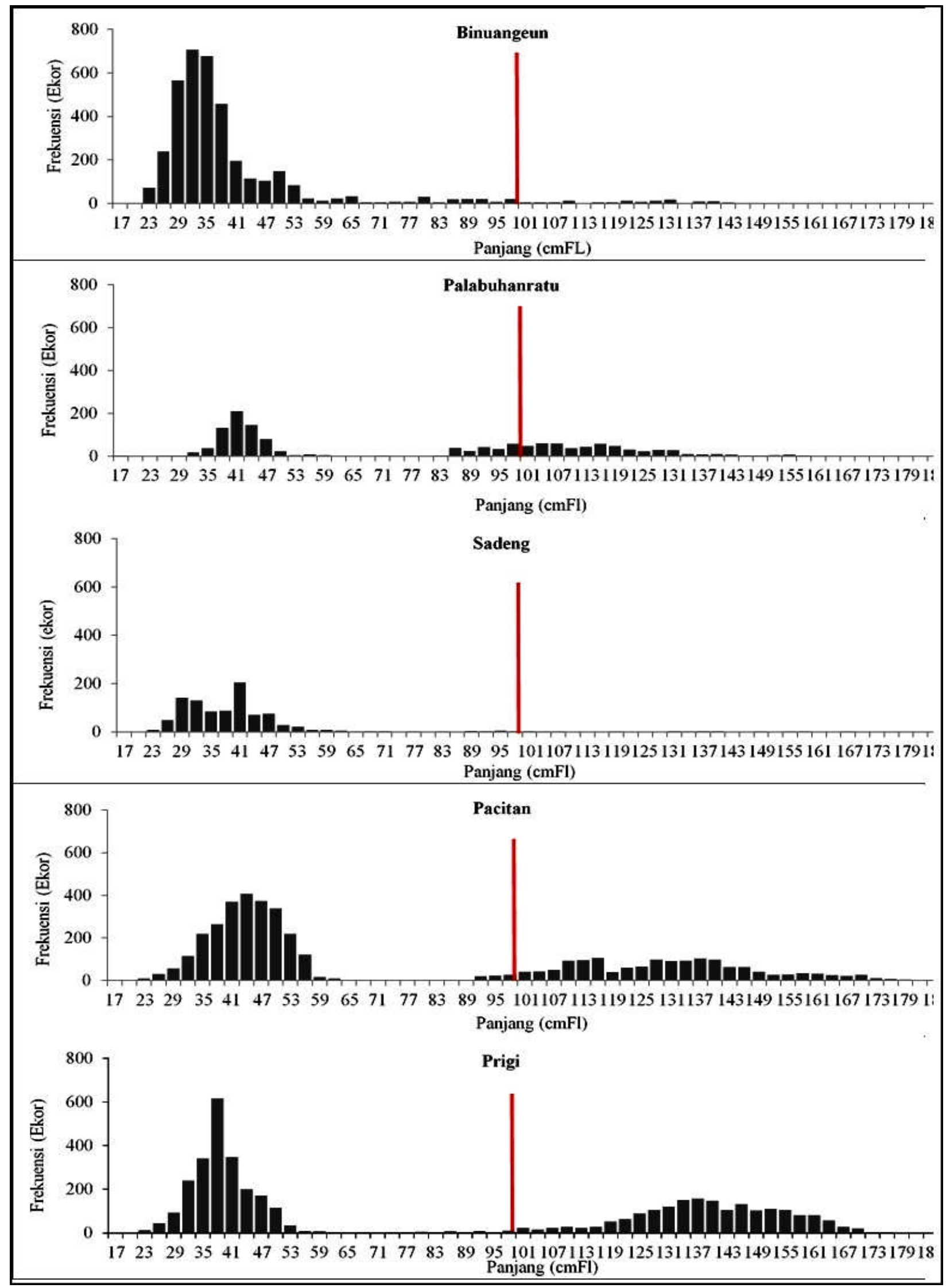

Gambar 4. Frekuensi panjang cagak ikan tuna sirip kuning yang tertangkap di selatan Jawa.

Figure 4. Fork length frequency of yellowfin tuna caught in southern part of Java. 


\section{Hubungan Panjang-Berat}

Data ukuran panjang dan berat tuna sirip kuning dikumpulkan dengan cara pengamatan dan pengukuran langsung terhadap tuna sirip kuning. Sebanyak 14.028 ekor tuna sirip kuning yang tertangkap di selatan Jawa diukur panjang dan beratnya. Berdasarkan hasil analisis hubungan panjang berat tuna sirip kuning di PPI Binuangeun dengan jumlah sampel 3456 ekor diperoleh persamaan $\mathrm{W}=0,0191 \mathrm{FL}^{2,9991}$ dengan nilai koefisien determinasi $\left(R^{2}\right)=0,9714$. Hasil uji t menunjukkan bahwa pertumbuhan tuna sirip kuning yang tertangkap di Binuangeun memiliki pola isometrik $(b=3)$, dimana pertambahan panjang sama dengan pertambahan berat. Sedangkan hubungan panjang berat di PPN Palabuhanratu dengan jumlah sampel 755 ekor didapatkan persamaan $\mathrm{W}$ $=0,0104 \mathrm{FL}^{3,1287}$ dengan nilai koefisien determinasi $\left(\mathrm{R}^{2}\right)=$ 0,9927. Hasil uji t menunjukkan bahwa pertumbuhan tuna sirip kuning yang tertangkap di PPN Palabuhanratu bersifat allometrik Positif $(b>3)$ dengan kata lain pertambahan berat lebih cepat dari pada pertambahan panjang. Untuk tuna sirip kuning yang tertangkap di PPP Sadeng mengikuti persamaan $\mathrm{W}=0,0281 \mathrm{~L}^{2,8681}$ dengan nilai koefisien determinasi $\left(\mathrm{R}^{2}\right)=0,9865$ dengan jumlah sampel 201 ekor. Sedangkan di P2SKP Pacitan ukuran panjang dan berat tuna sirip kuning yang berhasil diperoleh sebanyak 4.089 ekor dan memiliki persamaan $\mathrm{W}=$ $0,049 \mathrm{FL}^{2,7485}$ dengan nilai koefisien determinasi $\left(\mathrm{R}^{2}\right)=$ 0,9911. Sebanyak 4.155 ekor tuna sirip kuning yang berhasil dikumpulkan di PPN Prigi didapatkan persamaan $\mathrm{W}=$ $0,0313 \mathrm{FL}^{2,8543}$ dengan nilai koefisiensi determinasi $\left(\mathrm{R}^{2}\right)=$ 0,997. Sedangkan di P2SKP Sendang biru terdapat 1.372 ekor tuna sirip kuning yang diukur panjang beratnya dan memiliki persamaan $\mathrm{W}=0,454 \mathrm{FL}^{2,7726}$ dengan nilai koefisien determinasi $\left(\mathrm{R}^{2}\right)=0,9946$. Tuna sirip kuning yang tertangkap di PPP Sadeng, P2SKP Pacitan, PPN Prigi dan P2SKP Sendang Biru bersifat allometrik negatif $(b<3)$ dengan kata lain pertambahan panjang lebih cepat dari pada pertambahan berat (Gambar 5).

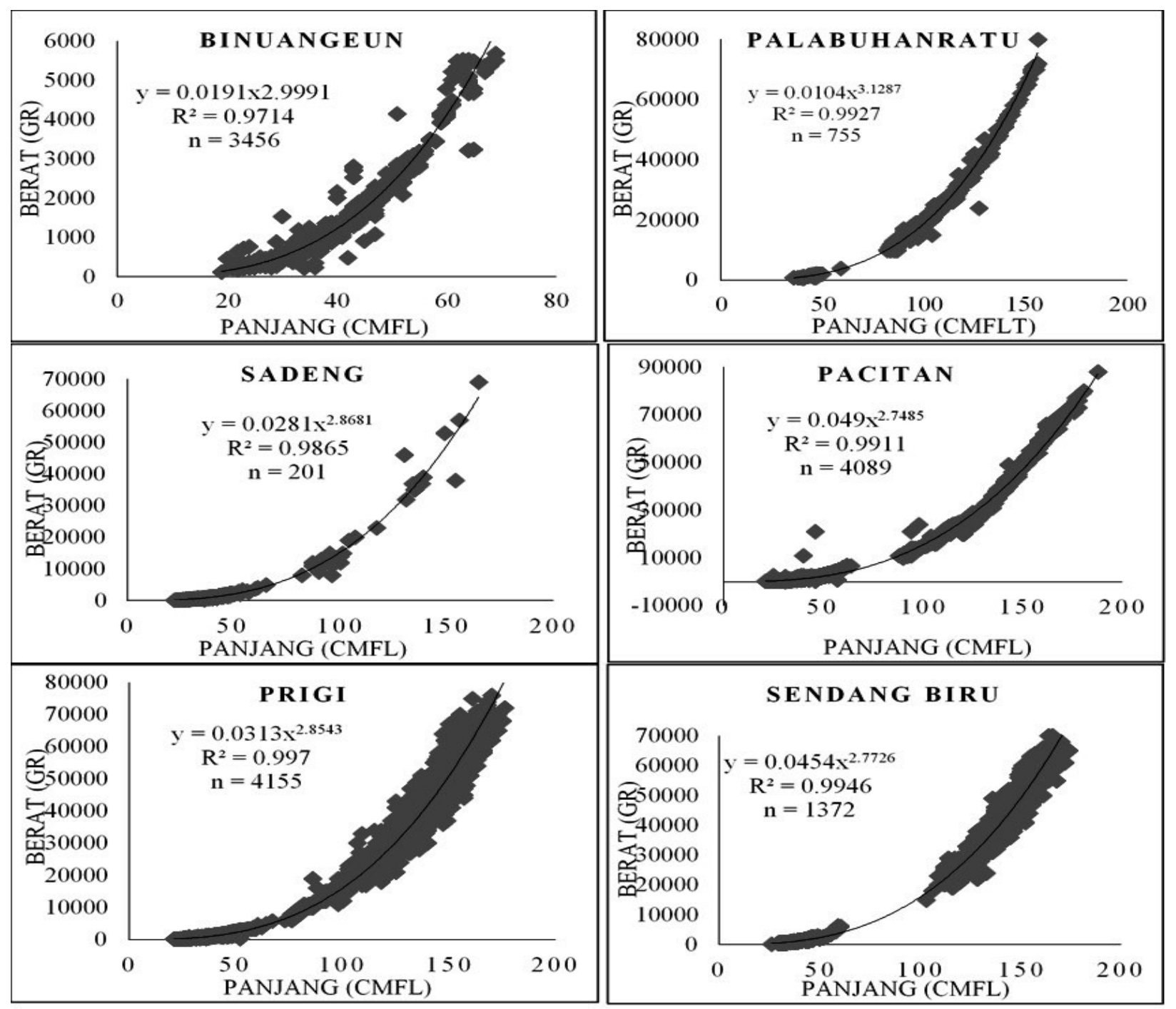

Gambar 5. Hubungan panjang berat tuna sirip kuning yang tertangkap di selatan Jawa.

Figure 5. Length weight relationship of yellowfin tuna caught in southern part of Java. 


\section{Faktor Kondisi}

Faktor kondisi relatif (Kn) Tuna sirip kuning adalah 0.96 dan cenderung berfluktuasi pada ikan-ikan berukuran kecil, sedangkan pada ikan yang dewasa menunjukkan kecenderungan yang menurun seiring dengan bertambahnya ukuran panjang. Faktor kondisi relatif tertinggi terjadi pada batas atas kelas panjang $20 \mathrm{~cm}$ sebesar 2.52 dan terendah terjadi pada batas atas kelas panjang $175 \mathrm{~cm}$ sebesar 0.69 (Gambar 5). Sedangkan faktor kondisi relatif perlokasi cenderung stabil dengan nilai tertinggi terjadi di Binuangeun sebesar 1,19 dan terendah terjadi di Sadeng sebesar 0.87 (Gambar 6).

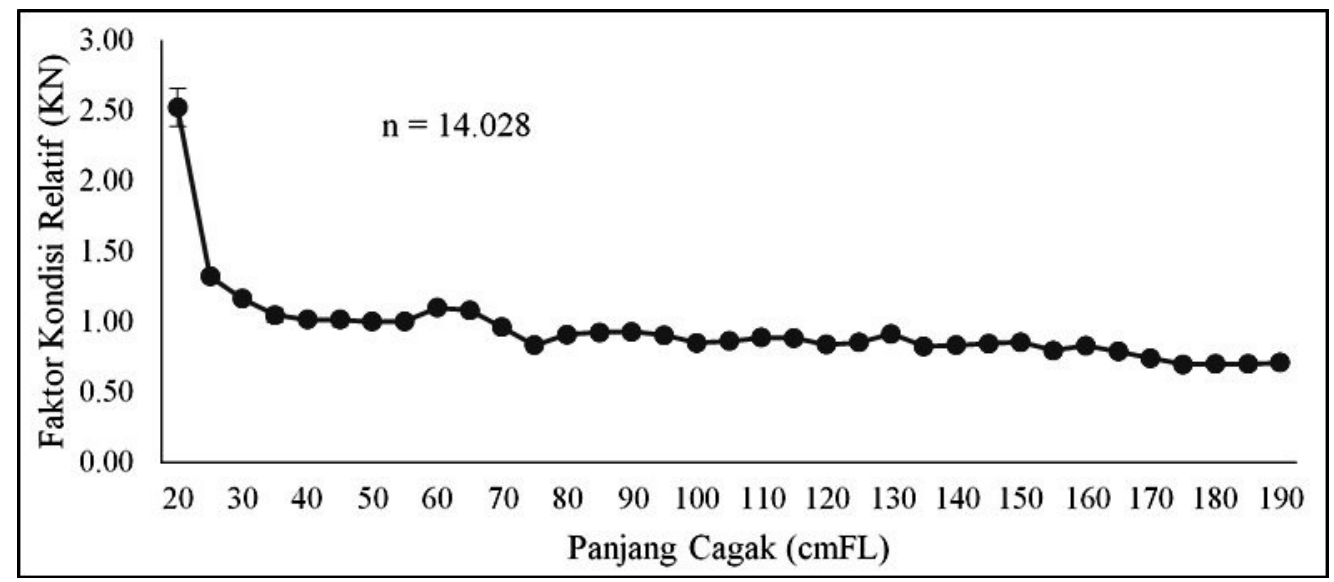

Gambar 6. Faktor kondisi relatif berdasarkan kisaran panjang Tuna Sirip Kuning (T. albacares). Figure 6. Relative condition factor of T. albacares according to the fish length.

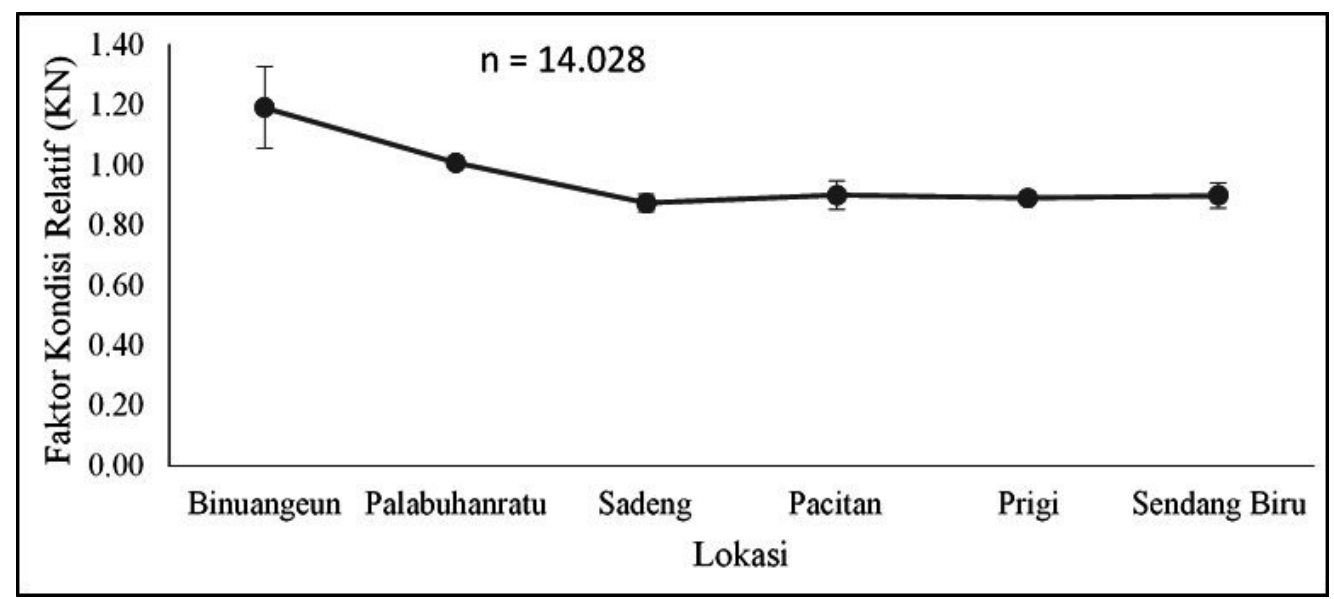

Gambar 7. Faktor kondisi relatif berdasarkan lokasi pendaratan Tuna Sirip Kuning (T. albacares).

Figure 7. Relative condition factor according to the landing sites.

\section{Bahasan}

Tingkat pemanfaatan tuna sirip kuning oleh nelayan skala kecil saat ini menunjukkan perkembangan yang sangat pesat. Armada tonda merupakan salah satu armada skala kecil yang banyak digunakan oleh nelayan dalam menangkap tuna sirip kuning. Alat tangkap yang digunakan dalam armada tonda yaitu pancing. Pancing tonda memiliki beberapa alat tangkap untuk menangkap ikan yaitu pancing tonda (pancing tonda panjang), pancing taber, pancing tomba, pancing coping dan pancing layang-layang. Keunggulan pengoperasian armada tonda dikarenakan dalam satu armada penangkapan dioperasikan empat alat tangkap sekaligus. Selain itu keunggulan pancing tonda diantaranya daerah penangkapan berada di sekitar rumpon sehingga produktivitas penangkapannya tinggi (Wudianto et al., 2003). Komposisi hasil tangkapan armada tonda di selatan Jawa didominasi oleh tuna sirip kuning dan cakalang. Hal ini karena tuna sirip kuning dan cakalang merupakan ikan yang berasosiasi dengan rumpon. Rumpon berfungsi sebagai alat pengumpul ikan. Kajian Cayre (1990) membuktikan bahwa rumpon dapat meningkatkan efesiensi penangkapan melalui ketepatan daerah penangkapan. Menurut Hidayat et al. (2014) dengan menggunakan rumpon maka migrasi ikan tuna akan tertahan di sekitar rumpon. Sebagaimana Fonteneau et al. (2000), menyatakan bahwa cakalang dan tuna sirip kuning mendominasi ikan yang berada di rumpon yaitu masingmasing sebesar $63 \%$ dan $25 \%$. Hal ini mengindikasikan bahwa penangkapan ikan dengan menggunakan armada 
tonda lebih efektif dibuktikan dengan adanya tangkapan ikan yang bernilai ekonomis tinggi. Akan tetapi memperhatikan ukuran ikan yang tertangkap armada tonda berukuran kecil, maka armada tonda ini dianggap masih kurang efektif dan masih memerlukan pengaturan ulang.

Penelitian sebelumnya yang dilakukan oleh Nurdin et al. (2015) terhadap komposisi hasil tangkapan pancing tonda di Palabuhanratu selama bulan April - Juli 2015 menunjukkan bahwa hasil tangkapan tuna didominasi oleh tuna sirip kuning (yellowfin tuna) sebesar 53,6\% dan cakalang (Katsuwonus pelamis) 29,54\%. Begitu juga dengan penelitian yang dilakukan Hargiyatno et al. (2013) selama bulan September - November 2010 menunjukkan hasil tangkapan armada tonda didominasi oleh tuna sirip kuning (Thunnus albacares) sebanyak $41 \%$ dan cakalang (Katsuwonus pelamis) sebanyak 28\%. Menurut Wahju et al. (2013) hasil tangkapan tuna dari armada tonda di perairan Palabuhanratu sangat dipengaruhi oleh faktor musim. Bulan Desember sampai Februari dikategorikan sebagai musim paceklik, sedangkan musim puncak yaitu Juni-September. Sedangkan menurut Faizah \& Aisyah, (2011), Hasil tangkapan pancing ulur yang didaratkan di Sendang Biru terutama jenis tuna sirip kuning dan tuna mata besar (Thunnus obesus). Pada bulan tertentu tertangkap juga jenis ikan tuna albakora (Thunnus alalunga). Jika dilihat dari komposisi hasil tangkapan di setiap lokasi semakin ke timur ikan albakora semakin banyak tertangkap oleh nelayan tonda. Suhu perairan memegang peranan penting dalam penyebaran albakora. Menurut Triharyuni et al. (2012), albakora berukuran kecil biasanya tertangkap di perairan dengan suhu rendah sedangkan albakora berukuran lebih besar banyak tertangkap di perairan yang lebih hangat. Albakora yang didaratkan di Cilacap banyak tertangkap di lokasi $10^{\circ}-14^{\circ}$ LS yang merupakan perairan dengan suhu relatif hangat. Jika dilihat dari daerah penangkapannya yang berada pada garis $10^{\circ}$ - $14^{\circ}$ LS, maka sama halnya dengan nelayan di Pelabuhan Sadeng, Pacitan, Prigi dan Sendang Biru yang banyak melakukan aktivitas pencarian ikan di lokasi tersebut, sehingga komposisi ikan albakor semakin banyak ditemui.

Analisis Catch Per Unit Effort (CPUE) tuna sirip kuning digunakan untuk mengetahui kelimpahan tuna sirip kuning suatu perairan dan tingkat pemanfaatan yang dihitung berdasarkan pembagian total hasil tangkapan (Catch) dengan upaya penangkapan (Effort). Nilai CPUE cenderung fluktuatif di setiap daerah pendaratan ikan di Selatan Jawa. Rata - rata nilai CPUE cenderung meningkat di bulan Maret - Mei kemudian menurun sampai Juli. Bulan Agustus nilai CPUE di setiap daerah mengalami kenaikan kembali dan mulai turun di bulan Oktober hingga akhir tahun. Nilai CPUE sendiri banyak dipengaruhi oleh faktor penangkapan dan kondisi perairan (Sadiyah et al., 2012). Menurut Sulistyaningsih et al. (2011) nilai CPUE tangkapan utama pancing ulur dipengaruhi beberapa faktor, salah satunya yaitu pengaruh musim. adanya gelombang dan angin besar mengakibatkan penurunan upaya penangkapan (trip). Sementara itu, Nurdin et al. (2018) mengatakan bahwa peningkatan CPUE armada tonda di Palabuhanratu terjadi pada saat musim timur yaitu antara bulan Juni hingga Agustus serta musim peralihan II, antara bulan September - November, dimana kondisi SPL rendah dengan kandungan klorofil-a yang tinggi. Nilai CPUE di beberapa daerah yang digunakan dalam penelitian ini juga serupa dengan hasil penelitian Nugroho et al. (2018) yang menunjukkan bahwa musim penangkapan ikan di barat Sumatera terjadi pada bulan Maret, April, Mei dan Oktober. Sedangkan bulan Januari, Februari, Juni, Juli, Agustus, November dan Desember bukan merupakan musim tangkap ikan.

Struktur ukuran tuna sirip kuning yang tertangkap di setiap lokasi rata-rata memiliki kesamaan dalam ukuran panjang ikan, kecuali di PPI Binuangeun, PPN Palabuhanratu dan PP Sadeng. Tuna sirip kuning yang tertangkap armada tonda di wilayah-wilayah tersebut memiliki ukuran yang kecil (juwana tuna) dan sangat jarang menangkap tuna sirip kuning yang berukuran besar. Hal ini berbeda dengan tuna sirip kuning yang tertangkap di P2SKP Pacitan, PPN Prigi dan P2SKP Sendang Biru, selain mendapat juwana tuna nelayan lokasi tersebut juga banyak mendapatkan tuna sirip kuning yang berukuran besar. Jika dilihat dari lokasi penangkapannya maka semakin ke arah timur semakin besar tuna sirip kuning yang tertangkap oleh nelayan tonda. Hal ini diduga dipengaruhi oleh faktor lingkungan dan kondisi perairan tersebut. Menurut Allain et al. (2005), faktor lingkungan perairan dapat mempengaruhi penyebaran tuna baik secara horisontal dan vertikal. Secara horisontal, daerah penyebaran tuna di Indonesia meliputi perairan barat dan selatan Sumatera, perairan selatan Jawa, Bali dan Nusa Tenggara, Laut Flores, Laut Banda, Laut Sulawesi dan perairan utara Papua. Secara vertikal, penyebaran tuna sangat dipengaruhi oleh suhu dan kedalaman renang.

Suhu pada setiap strata kedalaman juga mempengaruhi kelimpahan ikan tuna di suatu perairan. Berdasarkan penelitian Barata et al. (2011), jenis tuna sirip kuning dan albacore tertangkap pada kisaran kedalaman 35,15 - 299,04 $\mathrm{m}$ dengan suhu $12,51-26,96^{\circ} \mathrm{C}$. Jika dilihat dari kondisi tersebut diduga nelayan PPN Prigi, Pacitan dan Sendang Biru menangkap tuna sirip kuning di perairan yang lebih dalam. Hal tersebut karena tuna sirip kuning yang diperoleh memiliki ukuran lebih panjang dan albakor yang banyak tertangkap.

Ukuran ikan merupakan hal yang sangat penting diperhatikan. Hal ini dikarenakan dengan mengetahui panjang ikan, maka dapat menentukan kedewasaan dan ukuran layak tangkap ikan tersebut. Ukuran ikan layak tangkap adalah ukuran ikan pada panjang pertama kali 
matang gonad (length at first maturity $=\mathrm{Lm})$ (Jamal et al., 2011). Sebanyak 16.925 ekor tuna sirip kuning yang didaratkan mempunyai panjang cagak antara $23-168 \mathrm{~cm}$ FL. Jika dilihat dari ukuran panjang ikan tuna sirip kuning yang tertangkap diduga didominasi oleh juwana tuna sirip kuning dan belum pernah mengalami matang gonad atau melakukan pemijahan. Nilai ukuran pertama kali matang gonad tuna sirip kuning di Samudera Hindia sekitar 100 cmFL (Zhu et al., 2008). Jika di total dari seluruh ikan yang diukur panjangnya ikan yang belum pernah mengalami matang gonad sebanyak $71,63 \%$ dan yang sudah matang gonad $28,37 \%$. Sehingga dapat diketahui bahwa ikan tuna sirip kuning yang tertangkap di selatan Jawa dengan alat tangkap Pancing ulur sebagian besar adalah ikan yang belum layak tangkap. Hal ini sesuai dengan penelitian yang dilakukan oleh Hargiyanto et al. (2013) yang mengatakan bahwa tuna sirip kuning yang tertangkap oleh pancing tonda dan pancing ulur di Palabuhanratu pada umumnya berukuran kecil dan tergolong juvenile. Muhammad \& Barata, (2012) juga menjelaskan bahwa ikan tuna sirip kuning yang berukuran kecil (yuwana tuna) lebih banyak berkumpul di perairan sekitar rumpon. Begitupun dengan Nurhakim \& Suprapto, (2009) yang menyampaikan bahwa data produksi hasil tangkapan utama armada pancing ulur yuwana tuna sirip kuning yang didaratkan di Kedonganan lebih dominan $(82,97 \%)$ bila dibandingkan ikan tuna sirip kuning $(17,02 \%)$ yang berukuran besar. Hasil ini sangat berbeda dengan tuna sirip kuning yang tertangkap di laut banda. Berdasarkan penelitian yang dilakukan Damora \& Baihaqi, (2013), ikan tuna sirip kuning yang tertangkap pancing ulur di Laut Banda memiliki kisaran panjang cagak antara $55-215 \mathrm{~cm}$, dengan panjang pertama kali tertangkap (Lc) sebesar 131,85 cmFL. Hal ini diduga karena laut Banda merupakan alur migrasi sekaligus daerah mencari makanan bagi ikan-ikan tuna, khususnya ikan tuna sirip kuning.

Pola pertumbuhan tuna sirip kuning yang didaratkan di PPI Binuangeun memiliki pola pertumbuhan isometrik. Sementara itu, di PPN Palabuhanratu bersifat allometrik Positif $(b>3)$. Untuk tuna sirip kuning yang tertangkap di PPP Sadeng, P2SKP Pacitan, PPN Prigi dan P2SKP Sendang Biru bersifat alllometrik negatif $(\mathrm{b}<3)$. Berdasarkan hasil penelitian Nishida \& Sono, (2007), tuna sirip kuning di perairan Samudera Hindia tergolong pada pola pertumbuhan isometrik, yang artinya pertumbuhan tuna sirip kuning di perairan Samudera Hindia sebanding dengan pertumbuhan beratnya. Sedangkan analisis hubungan panjang dan berat yang dilakukan oleh Darondo et al. (2014) menunjukkan bahwa pertumbuhan tuna sirip kuning yang di daratkan di PPS Bitung, memiliki pola pertumbuhan allometrik positif ( $b>3$ ), dengan kata lain pertambahan berat lebih cepat dari pada pertambahan panjang. Perbedaan laju pertumbuhan dapat dipengaruhi oleh dua faktor yaitu faktor internal yang meliputi umur dan jenis ikan dan faktor eksternal yang meliputi lingkungan dan kondisi perairan (Breet, 1979; Kamler, 1992 dan wootton, 1998 dalam Schluderman et al., 2009). Csirke (1980) dalam Hartaty dan Sulistyaningsih, (2014) lebih lanjut menyatakan bahwa faktor lingkungan mempengaruhi perbedaan nilai pertumbuhan dari spesies ikan yang sama pada lokasi yang berbeda. Faktor lingkungan tersebut seperti ketersediaan makanan, suhu perairan dan oksigen terlarut. Sementara itu, menurut Sukimin et al. (2002), faktor lingkungan dan jenis serta ukuran makanan yang dimakan dapat mempengaruhi sifat pertumbuhan. Selain hal tersebut perbedaan pola pertumbuhan di setiap lokasi dapat disebabkan oleh perbedaan musim dan tingkat kematangan gonad serta aktivitas penangkapan karena aktivitas penangkapan yang cukup tinggi pada suatu daerah cukup mempengaruhi kehidupan dan pertumbuhan populasi ikan (Sumadhiharga, 1991).

Hasil penelitian menunjukkan bahwa, faktor kondisi relatif $(K n)$ Tuna sirip kuning yang tertangkap dengan armada tonda adalah 0.96. Terjadi fluktuasi nilai faktor kondisi rata-rata ikan tuna sirip kuning pada setiap ukuran. Faktor kondisi yang paling tinggi terjadi pada ukuran ikan yang lebih kecil yaitu $20-65 \mathrm{cmFl}$ dengan nilai faktor kondisi rata-rata yaitu $2.52-1.08$, sementara faktor kondisi yang lebih kecil terjadi pada ukuran ikan yang lebih besar yaitu dengan panjang $70-190 \mathrm{cmFl}$ dengan nilai faktor kondisi sebesar $0.69-0.96$. Hal serupa juga ditunjukkan dari hasil penelitian Faizah \& Aisyah, (2011), faktor kondisi rata-rata untuk ikan tuna sirip kuning yang didaratkan di Sendang Biru adalah 1,66 dengan faktor kondisi yang paling tinggi terjadi pada ukuran ikan yang lebih kecil dan faktor kondisi yang lebih kecil terjadi pada ukuran ikan yang lebih besar. Hal ini diduga karena adanya fase reproduksi tuna sirip kuning yang mengalami pertama kali matang gonad pada ukuran $100 \mathrm{cmFL}$ (Zhu et al., 2008) sehingga menambah berat tubuh ikan (faktor kemontokan). Faizah \& Aisyah, (2011) juga mengatakan bahwa perbedaan faktor kondisi antara ikan kecil dan ikan besar disebabkan oleh adanya perbedaan pertumbuhan dan tingkat kematangan gonad dari masing-masing ikan. Pada ukuran ikan kecil ada ikan yang masih dalam proses pertumbuhan somatik sehingga secara fisik tubuh ikan lebih cepat berkembang dan faktor kondisinya menjadi lebih besar, sementara pada ukuran yang lebih besar atau ikan dewasa yang akan memijah, energi yang diperoleh digunakan untuk proses kematangan gonadnya sehingga menyebabkan faktor kondisinya lebih kecil.

Sedangkan faktor kondisi relatif untuk masing-masing lokasi pendaratan cenderung stabil. Nilai faktor kondisi relatif tertinggi terjadi di Binuangeun sebesar 2,52 dan terendah di Sadeng dengan nilai 0.69. Lingkungan perairan dan sumber makanan yang relatif sama di perairan Samudera Hindia diduga menjadi salah satu faktor yang mempengaruhi nilai faktor kondisi relatif tuna sirip kuning cenderung stabil. Nilai Faktor kondisi relatif dipengaruhi oleh kepadatan populasi, tingkat kematangan gonad, 
makanan, jenis kelamin, dan umur ikan (Effendie, 2002). Faktor kondisi dapat menunjukkan indikasi keadaan baik atau tidaknya panjang berat ikan yang dinyatakan dalam angka dan dilihat dari segi kapasitas fisik untuk survival dan reproduksi (Effendie, 1997). Faktor kondisi ikan tuna sirip kuning yang didaratkan dengan alat tangkap armada tonda mengindikasikan dalam kondisi yang baik dan dapat dikonsumsi dengan nilai $0,69-2,52$.

\section{KESIMPULAN}

Tuna sirip kuning dan cakalang merupakan hasil tangkapan terbesar dari armada tonda di seluruh pendaratan ikan tuna di selatan Jawa. CPUE berfluktuasi di setiap lokasi pendaratan tuna sirip kuning di selatan Jawa. Sebagian besar tuna sirip kuning yang tertangkap di selatan Jawa dengan alat tangkap pancing ulur adalah ikan yang belum layak tangkap. Ukuran tuna sirip kuning yang tertangkap semakin ke arah timur, yang tertangkap semakin besar. Pola pertumbuhan tuna sirip kuning yang tertangkap di Binuangeun memiliki pola isometrik; di PPN Palabuhanratu bersifat allometrik positif, sementara di PPP Sadeng, P2SKP Pacitan, PPN Prigi dan P2SKP Sendang Biru bersifat allometrik negatif.

\section{PERSANTUNAN}

Penelitian ini dibiayai dari DIPA kegiatan riset Loka Riset Perikanan Tuna (LRPT) pada tahun 2016. Peneliti mengucapkan terima kasih kepada enumerator dan PJ lokasi di PPI Binuangeun, PPN Palabuhanratu, PPP Sadeng, P2SKP Tamperan, PPN Prigi dan P2SKP Pondok Dadap yang telah membantu dalam proses pengumpulan data penelitian ini.

\section{DAFTAR PUSTAKA}

Allain, G., Lehodey, P.., Kirby, D. S., \& Leroy, B. (2005). The Influence of the environment on Horizontal and Vertical Bigeye Tuna Movements Investigated by Analysis of Archival tag Records and Ecosystem Model Outputs. WCPFC-SC1, 3:13p.

Barata, A., Novianto, D., \& Bahtiar, A. (2011). Sebaran ikan tuna berdasarkan suhu dan kedalaman di Samudera Hindia. ILMU KELAUTAN, 16(3), 165-170. https://doi.org/10.14710/ik.ijms.16.3.165-170

Cayre, P. (1990). "Behaviour of yellow fin tuna (Thunnus albacares) and skipjack tuna (Katsuwonus pelamis) around FADs in the Comoros Islands as determind by ultrasonic tagging". Aqua Living Resour, 4. 1-12.

Damora, A., \& Baihaqi. (2013). Struktur ukuran ikan dan parameter populasi tuna sirip kuning (Thunnus albacares) di Perairan Laut Banda. BAWAL, 5(1), 5965. http://dx.doi.org/10.15578/bawal.5.1.2013.59-65

Darondo, F.A., Manoppo, L., \& Luasunaung, A. (2014). Komposisi tangkapan tuna hand line di pelabuhan perikanan Samudera Bitung, Sulawesi Utara. Jurnal Ilmu dan Teknologi Perikanan Tangkap, 1(6), 227232. https://doi.org/10.35800/jitpt.1.6.2014.6962

Direktorat Jenderal Perikanan Tangkap. (2012). Statistik Perikanan Tangkap Indonesia 2011. Kementerian Kelautan dan Perikanan, Jakarta. 190 pp.

Effendie, M.I. (1997). Biologi perikanan (p. 163). Yayasan Pustaka Nusatama. Yogyakarta.

Effendie, M.I. (2002). Biologi perikanan (p. 112). Yayasan Pustaka Nusatama. Yogyakarta.

Faizah, R., \& Aisyah. (2011). Komposisi Jenis Dan Distribusi Ukuran Ikan Pelagis Besar Hasil Tangkapan Pancing Ulur di Sendang Biru, Jawa Timur. BAWAL, $3(6), \quad 377-385$. http://dx.doi.org/10.15578/ bawal.3.6.2011.377-385

Fonteneau, A., Farales, P., \& Pianet, R. (2000). "Aworidwide review of purse seine fisheries on FADs". Session I. Regional Syntheses. p, 15-35.

Hargiyatno, I.T, Anggawangsa, R.F., \& Wudianto. (2013). Perikanan pancing ulur di Palabuhanratu/ : Kinerja Teknis Alat Tangkap Hand Lines Fishery in Palabuhanratu/ . J. Lit. Perikan. Ind. 19(3), 121-30. http://dx.doi.org/10.15578/jppi.19.3.2013.121-130

IOTC (Indian Ocean Tuna Commission). (2016). Report of the Twelve Session of the IOTC Working Party on Data Collection \& Statistic. Victoria, Seychelles. 2830 November $2016.37 \mathrm{p}$.

Jamal, M., Sondita, M.F.A., Haluan, J., \& Wiryawan, B. (2011). Pemanfaatan data biologi ikan cakalang (Katsuwonus pelamis) dalam rangka pengelolaan perikanan bertanggung jawab di Perairan Teluk Bone. Jurnal Natur Indonesia, 14(1), 107-113. ISSN 14109379

King, M. (2007). Fisheries biology, Assessment and Management (p. 381). Second edition. Blackwell Sciencetific Publication. Oxford.

Muhammad, N., \& Barata, A. (2012). Struktur Ukuran Ikan Tuna sirip kuning (Thunnus Albacares) yang Tertangkap Pancing Ulur di Sekitar Rumpon Samudera Hindia Selatan Bali Dan Lombok. BAWAL, 4(3), 161167. 
Nishida, T., \& Sono, H. (2007). "stock assessment of yellowfin tuna (Thunnus albacares) in the Indian Ocean by the Age Structured Production Model (ASPM) Analysis". Submitted to the IOTC 9th WPTT Meeting, July 16-20. Victoria: 1-17. Halaman 3-4.

Nugroho, S.C., Jatmiko, I., \& Tampubolon, P.A.R.P. (2018). Struktur Ukuran, Hasil Tangkapan Per Unit Upaya dan Musim Penangkapan Tuna Mata Besar (Thunnus obesus Lowe, 1839) di Bagian Timur Samudera Hindia. J.Lit.Perikan.Ind. 24(3), 217-225. http://dx.doi.org/ 10.15578/jppi.24.3.2018.\%25p

Nurdin, E., Sondita, M.F.A., Yusfiandayani, R., \& Baskoro, M. (2015). Produktivitas dan musim penangkapan ikan tuna sirip kuning (Thunnus albacares Bonnaterre, 1788) pada Perikanan Skala Kecil di Palabuhanratu, Jawa Barat. J.Lit.Perikan.Ind. 21(3), 147 - 154. http:// dx.doi.org/10.15578/jppi.21.3.2015.147-154

Nurdin, E., \& Nugraha, B. (2007). Penangkapan tuna dan cakalang dengan menggunakan alat tangkap pancing ulur (Hand Line) yang Berbasis di Pangkalan Pendaratan Ikan Pondokdadap Sendang Biru, Malang. BAWAL. 2(1), 27 - 33. http://dx.doi.org/10.15578/ bawal.2.1.2008.27-33

Nurdin, E., Panggabean, A.S., \& Restiangsih, Y.H. (2018). Pengaruh Parameter Oseanografi Terhadap Hasil Tangkapan Armada Tonda di Sekitar Rumpon di Palabuhanratu. J.Lit. Perikan. Ind. 2(2), 117-126. http:/ /dx.doi.org/10.15578/jppi.24.2.2018.117-128

Nurhakim, S., \& Suprapto. (2009). Laporan teknis riset; kebijakan pemanfaatan hasil tangkapan sampingan perikanan tuna di Samudera Hindia. Balai Riset Perikanan Laut. Pusat Riset Perikanan Tangkap. Jakarta: 29 p.

Sadiyah, L., Dowling, N., \& Prisantoso, B. I. (2012). Developing recommendations for undertaking CPUE standardization using observer program data. Ind.Fish.Res.J. 18(1), 19-33. http://dx.doi.org/10.15578/ ifrj.18.1.2012.19-33

Schluderman, E. Keckeis, H., \& Nemeschkal, L. (2009). Effect of initial size on daily growth and survival in freshwater Chondrostoma nasus larvae: a field survey. Journal of Fish Biology, 74, 939-955. https://doi.org/ 10.1111/j.1095-8649.2009.02182.x

Sparre, P., \& Venema, S. C. (1999). Introduksi Pengkajian Stok Ikan Tropis. Buku 1: Manual. Terjemahan dari Introduction to Tropical Fish Stock Assessment Part
1: Manual. Food and Agriculture Organization Fisheries Technical Paper Number 306/1. Food and Agriculture Organization of the United Nation. Jakarta. 554 hal.

Steel R.G.H \& Torrie J.H. (1989). Prinsip dan Prosedur Statistika: Suatu Pendekatan Biometrik (Terjemahan dari Principle and procedure of statistic: a biometri approach). Sumantri B (penerjemah). Edisi kedua. PT.Gramedia. Jakarta. 748 pp.

Sukimin, S., Isdrajat, S., \& Yon Vitner. (2002). Petunjuk praktikum biologi perikanan. Fakultas Perikanan dan Ilmu Kelautan. Institut Pertanian Bogor. Bogor.

Sulistyaningsih, R.K., Barata, A., \& Siregar, K. (2011). Perikanan pancing ulur tunadi kedonganan, Bali. $J$. Lit. Perikan. Ind. 17(3), 185-191. http://dx.doi.org/ 10.15578/jppi.17.3.2011.185-191

Sumadhiharga, K. (1991). Struktur populasi dan reproduksi ikan momar merah (Decapterus ruselli) di teluk Ambon. Di dalam: BPPSL. Pusat penelitian dan Pengembangan Oseanologi - LIPI. Perairan Muluku dan Sekitarnya.

Hidayat T., Chodrijah U., \& Noegroho T. (2014). Karakteristik Perikanan Pancing Tonda di Laut Banda. J. Lit. Perikan. Ind.18 (1), 35-41. http://dx.doi.org/ 10.15578/jppi.20.1.2014.43-51

Triharyuni, S., Sulaiman P. S., \& Rianto, J. (2012). Hubungan panjang berat, tingkat eksploitasi dan fluktuasi hasil tangkapan albakora (Thunnus alalunga, Bonnaterre) di Samudera Hindia. J. Lit. Perikan. Ind. 8 (1), 35 -41. http://dx.doi.org/10.15578/jppi.18.1.2012.35-41

Wahju, R.I, Zulbainarni, N., \& Soeboer, D.A. (2013). Hasil Tangkapan Pancing Tonda Berdasarkan Musim Penangkapan dan Daerah Penangkapan Tuna dengan Rumpon di Perairan Selatan Palabuhanratu. BULETIN PSP 21(1), 97-105

Wudianto, Wagiyo, K., \& Wibowo, B. (2003). Sebaran daerah penangkapan tuna di Samudera Hindia. J. Lit. Perikan. Ind. Edisi Sumberdaya dan Penangkapan. 9(7), 19-28. http://dx.doi.org/10.15578/jppi.9.7.2003.1927

Zhu, G., L. Xu., Y. Zhou., \& X. Dai. (2008). LengthFrequency Compotitions and Weight-Length Relation for Big-Eye Tuna, Yellowfin Tuna and Albacore (Percoformes: Scombrinae) in the Atlantic, Indian and Eastern Pasific Oceans. Acta Ichthyologica et piscatoria. 38(2), 157 - 161. DOI: 10.3750/ AIP2008.38.2.12 